\title{
Validation of the content of a children's game to promote the nursing profession
}

\section{Luísa Maria da Costa Andrade \\ Maria Manuela Ferreira Pereira da Silva Martins ${ }^{a}$ \\ Carla Sílvia Fernandes ${ }^{a}$ \\ Henriqueta Ilda Verganista Martins Fernandes ${ }^{a}$}

How to cite this article: Andrade LMC, Martins MMFPS, Fernandes $C$, Fernandes HIVM. Validation of the content of a children's game to promote the nursing profession. Rev Gaúcha Enferm. 2021;42:e20200435. doi: https://doi.org/10.1590/19831447.2021.20200435
Escola Superior de Enfermagem do Porto (ESEP) Centro de Investigação em Tecnologias e Serviços de Saúde. Porto, Portugal.

\section{ABSTRACT}

Objective: To validate content for an experimental game named Quantos Queres, using an origami, about the Nursing profession, for children from 7 to 12 years old.

Method: Methodological study that included two groups of experts: $A(n=7), B(n=40)$. Non-probabilistic sampling approach was used. We used a self-completion form, available by email and social networks, in Portugal, between February and April 2020. Acceptance decision established for $75 \%$ agreement.

Results: The groups were mostly composed by nurses. Group A identified the themes: professional profile, training, ethical principles, historical and symbolic elements and conceived the content of the statements in the form of questions and answers. In group $B$, agreement was higher than $75 \%$ in the areas and contents of the statements.

Conclusion: The selection of content to integrate the game is essential. The agreement obtained shows the importance of the chosen themes and the adequacy to the purpose that will be tested later.

Keywords: Nursing. Children. Experimental games. Social marketing.

\section{RESUMO}

Objetivo: Validar conteúdo para um jogo experimental, designado por Quantos Queres, utilizando um origami, sobre a profissão de Enfermagem, para crianças dos 7 aos 12 anos.

Método: Estudo metodológico, incluiu dois grupos de peritos: A $(n=7), B(n=40)$. Amostragem não probabilística. Utilizado formulário de autopreenchimento, disponibilizado por e-mail e redes sociais, em Portugal, entre fevereiro e abril de 2020. Decisão de aceitação estabelecida para 75\% de concordância.

Resultados: Os grupos foram majoritariamente constituídos por enfermeiras. Grupo A identificou as temáticas: perfil profissional, formação, princípios éticos, elementos históricos e simbólicos e concebeu o conteúdo dos enunciados em forma de perguntas e respostas. No grupo B obteve-se a concordância superior a 75\% nas áreas e nos conteúdos dos enunciados.

Conclusão: A seleção do conteúdo a integrar o jogo é fundamental. A concordância obtida evidencia a importância dos temas eleitos e a adequação à finalidade que será testada posteriormente.

Palavras-chave: Enfermagem. Criança. Jogos experimentais. Marketing social.

\section{RESUMEN}

Objetivo: Validar lo contenido de un juego experimental, Ilamado Quantos Queres, basado en el origami, sobre la profesión de enfermera, para niños de 7 a 12 años.

Método: Estudio metodológico, incluyó dos grupos de expertos: A $(n=7), B(n=40)$. Muestreo no probabilístico. Formulario disponible por correo electrónico y redes sociales, en Portugal, entre febrero-abril de 2020. La aceptación se estableció para una concordancia del $75 \%$

Resultados: Grupos compuestos en su mayoría por enfermeras. El Grupo A identificó los temas: perfil profesional, formación, principios éticos, elementos históricos y simbólicos y diseñó el contenido de las declaraciones en forma de preguntas y respuestas. Grupo B obtuvo más de un $75 \%$ de acuerdo sobre las áreas y el contenido de las declaraciones.

Conclusión: La selección del contenido a integrar en el juego es fundamental. El acuerdo obtenido evidencia la importancia de los temas elegidos y la adecuación al propósito que será probado posteriormente.

Palabras clave: Enfermeria. Niño. Juegos experimentales. Mercadeo social. 


\section{口INTRODUCTION}

The image of the nursing profession is essential for those who practice it and for the society in which it is practiced. Its recognition favors the maximum potential of its development. For this reason, it is important to intervene in society, and, with the young people, as seeds of social transformation. In childhood, values, habits and lifestyles are formed and intellectual and social acquisitions take place - understanding of concepts, objects and actions - to which each child attributes meanings. This is the moment when its entire development plan fits into a logic of productivity and action ${ }^{(1)}$. We consider it important to develop an experimental game for children that allows them to access information about the nursing profession using a playful strategy.

Nursing thinking, like other disciplinary areas, evolved as a result of current social paradigms. The nursing profession has ancestral roots in the art of caring for the family by women. However, it was only in the 19th century, with Nightingale, that its professionalization began with a body of theoretical and practical knowledge. Currently, and considering the ecological paradigm, nursing professionals are required to act centered on the interpersonal relationship with the person and groups in order to help them to be proactive in achieving their health projects ${ }^{(2)}$. The role of the profession is recognized by society for contributing to the quality of healthcare provided. However, its visibility is diluted in the multidisciplinary health space, often going unnoticed and misunderstood. Its social value is associated with the process of building a professional image, conditioned by stereotypes associated with its origin and sociocultural context. Its social image is permeated by stereotypes associated with the evolution and paradigms that crossed the profession, creating a discrepancy between its image and its effective role. The maintenance of this image is supported by the existence of the hierarchy -traditional images of the profession ${ }^{(3-5)}$.

Changing this representation and understanding the role of nursing will take years. Currently, the experience of the COVID-19 pandemic is added to these factors, which places the profession in the face of the inability to infer meanings from the events that emerge from it due to the limitation of knowledge and skills and the physical and emotional overload that led to the restructuring and reorganization of the multiple contexts where nurses work. This perspective shows that the social image of nurses is changing, as they recognize that their emotional well-being in times of pandemic improves through the recognition of their efforts - hospital management bodies, government and communities ${ }^{(6)}$.

Professional marketing includes the campaign promoted by the World Health Organization and the Nursing Now
International Council of Nurses. This campaign aims to improve health globally, increasing the profile and status of Nursing worldwide through the development of new models, participation in health policies, recognition of skills, dissemination of effective and innovative practices and investment in improving working conditions ${ }^{(6-7)}$.

We are at the right time to revert the invisibility of the nursing profession and its implications for people's health, to achieve changes in the perception and behavior of citizens, with a special focus on children, due to their potential for change.

In childhood, recreational activities are a resource for balanced growth and development. In this context, the game as a playful activity cooperates in the formation of knowledge mediating significant learning. But its contribution will depend on the game design, the child and the context. In the school space, the experimental game is an educational instrument and in the cultural space, the game is an instrument for learning social rules. In both contexts, the child learns by having fun ${ }^{(8-9)}$. The game is a cornerstone of learning and, consequently, of education, through the association of two main ingredients: pleasure and knowledge. This position goes against the thought of Lev Vygotsky, who considered the playful game as a factor that enables the child to learn to act, to develop language, thought, concentration and creativity ${ }^{(10)}$. It is unknown any study that has explicitly and exclusively investigated the phenomenon of the image and the role of the nurse portrayed through an origami.

Assuming that learning represents in Human Life the development of knowledge and that it is processed in different ways in the different stages of life, and that it must have characteristics that involve interest, the desire to know and learn, the curiosity to question, the pleasure and joy in discovery(10), we have the research question: What contents should integrate an experimental game, promoting the nursing profession and aimed at children?

Thus, the objective of this article is to validate content for an experimental game named Quantos Queres, using an origami, about the Nursing profession, for children aged 7 to 12 years old.

\section{$\square$ METHOD}

Methodological study, whose data collection method was an expert panel. The formal methods of consensus, through the group of experts, is an increasingly used tool in the resolution of health problems, for the definition of levels of agreement on controversial issues, as it allows flexibility in data processing, efficiency in taking decisions, the legitimacy of content and increased reliability ${ }^{(11-13)}$. 
This study was developed with the aim of creating the content of a game for children aged 7 to 12 years old, which includes a playful component and a didactic component with which it is intended to make known the nursing profession.

Previously, the game structure was defined for which there were some requirements: it had to be appealing, potentializing cognitive and motor skills, viable and economical. The use of the origami technique: (ori) folding (kami) paper or folding technique, implemented as the term itself says in folding sheets of paper with edges, vertices, faces, among others, creating figures of two or three dimensions was the solution that best responded to the above requirements. Origami has been implemented, practiced, and developed in early childhood education in Japan for the past 140 years. It has cheap and available teaching material: it is a simple colored square and leftover used in various fields (mathematics, engineering, space technology, cultural studies, education, creative design, psychology and health care ${ }^{(14)}$.

The origami, Quantos Queres, must be previously constructed by the child to be played involves at least two participants: whoever has the origami asks the other participant to choose a number and moves the Quantos Queres as many times as requested (join and spread the fingers sideways and forward to move it). In the number that finishes the count, four colors are visible. The opponent chooses a color and in the chosen color, whoever has the "quantos queres" opens the triangle and at the top of it appears the question that the second participant must answer, and the corresponding answer is at the bottom.

The selection of items to be included in the game that best make known the profession must be carefully selected. To identify the thematic areas of the nursing profession to be included in the experimental game and the design of its statement, two groups of experts were formed, designated by $A$ and $B$, whose sampling was non-probabilistic recruited in a snowball.

Group A consisted of seven expert-researchers. For their selection, the inclusion criteria were: postgraduate training in nursing, with a PhD and experience in instrument validation. The exclusion criterion was not to exercise their professional activity in the national territory of Portugal. The invitation and presentation of the project was made by email.

Data collection took place in two moments, February and June 2020 in a meeting room of the institution promoting the study. In addition to the experts, two elements of the research group were present, one in the role of moderator and the other of observer with the task of gather the information.

This group had as its main objective the selection of content, considering conceptual adequacy, relevance and clarity.
This discussion resulted in a form consisting of 19 questions referring to: the characterization of the experts in group $B$ (gender, age, area of professional activity); eight questions to obtain the agreement of the statement considering relevance and clarity, using a two-item scale - agree and disagree and eight open questions to identify suggestions from other relevant thematic areas or new wording for the statements of the questions/answers considering their clarity.

In the selection of group $B$, the following inclusion criteria were applied: being an education or health professional with expertise in working with children aged between 7 and 12 years old. The exclusion criteria were: working for less than five years with this age group and not exercising their professional activity in the national territory of Portugal.

The invitation to the experts was sent by email or social networks up to a total of 40 participants, and the sample was calculated based on the principle of five answers for each question. Data collection was carried out exclusively by email or social networks, which made participation easier and allowed the elimination of personal interactions, reducing the influence of a psychological nature, such as the effects of persuasiveness and the predominance of most opinions ${ }^{(12)}$.

The form was self-filled electronically, through Google Forms ${ }^{\oplus}$, entitled "Nursing through the eyes of children" "A Enfermagem pelo olhar das crianças" and the collection period took place between February and April 2020. The acceptance decision was established by consensus of 75\% agreement for each item.

The second meeting of the group of experts took place in June with the objective of analyzing and establishing the contents to be integrated into the game considering the proposals of experts group B (Box 1).

For the statistical treatment of the data, we used the SPSS 24 for Windows (Statistical Package for the Social Sciences ${ }^{\circledR}$ ). The analysis included descriptive and inferential statistics. Given the characteristics of the data, non-parametric tests were used to understand the differences between experts. A 95\% confidence interval was adopted with a p value of less than 0.05 and using the Mann-Whitney $U$ test and the Kruskal-Wallis test. For content evaluation, we used an electronic agreement.

In the ethical aspects, confidentiality and anonymity were guaranteed by the codification of the data obtained and by the voluntary acceptance, by all participants, of the informed consent, which appeared at the beginning of the form. It was approved by the Research Ethics Committee of the Escola Superior de Enfermagem do Porto, with opinion ADHOC_1055/2020. 


\begin{tabular}{|c|c|}
\hline Steps & Description \\
\hline $\begin{array}{l}\text { 1st Selection of strategy to make the } \\
\text { nursing profession known to children }\end{array}$ & A game that included a playful and a didactic component \\
\hline 2nd Game selection & $\begin{array}{l}\text { The game Quantos Queres, which is built using the origami technique, } \\
\text { was the option because it responds to requirements: appealing, enhances } \\
\text { cognitive and motor skills, easy and economical to materialize. }\end{array}$ \\
\hline $\begin{array}{l}\text { 3rd Definition of selection criteria for } \\
\text { group A experts }\end{array}$ & $\begin{array}{l}\text { Researchers with postgraduate training in nursing, with a PhD and } \\
\text { experience in instrument validation }\end{array}$ \\
\hline $\begin{array}{l}\text { 4th Identification and contact with } \\
\text { group A experts }\end{array}$ & Directed invitation and project presentation, in February, by email \\
\hline 5th First meeting of Group A Experts & $\begin{array}{l}\text { Selection and discussion of content. Eight question and answer statements } \\
\text { resulted to be included in the game } \\
\text { Took place in February }\end{array}$ \\
\hline $\begin{array}{l}\text { 6th Definition of selection criteria for } \\
\text { group B experts }\end{array}$ & $\begin{array}{l}\text { Education or health professional; } \\
\text { Working with children between } 7 \text { and } 12 \text { years old }\end{array}$ \\
\hline $\begin{array}{l}\text { 7th Identification and contact with } \\
\text { group B experts }\end{array}$ & $\begin{array}{l}40 \text { snowball experts were recruited } \\
\text { The invitation was sent by e-mail or social media }\end{array}$ \\
\hline $\begin{array}{l}\text { 8th Submission of form to group } \\
\text { B experts }\end{array}$ & $\begin{array}{l}\text { Submitted, link to the questionnaire, in the Google forms } s^{\oplus} \text { app between } \\
\text { February and March, requesting responses by the end of April }\end{array}$ \\
\hline $\begin{array}{l}\text { 9th Analysis of the results of the group } \\
\text { B experts }\end{array}$ & Answers were analyzed by agreement criteria (among experts $\geq 75 \%$ ) \\
\hline $\begin{array}{l}\text { 10th Second meeting of group } \\
\text { A experts }\end{array}$ & $\begin{array}{l}\text { Analysis and discussion of results and content review in light of the } \\
\text { proposals of group B experts }\end{array}$ \\
\hline
\end{tabular}

Box 1 - Steps taken throughout the study. Portugal, 2020 Source: Research data, 2020.

\section{RESULTS}

Group A, composed of seven expert-researchers, mostly female (85.7\%); 71.4\% with a PhD in Nursing Sciences, 28.6\% in the area of Educational Sciences and all had experience in instrument validation considering the conceptual adequacy, relevance and clarity. They identified the thematic areas to be included in the content of the statements: history, professional practice, training and ethics and deontology in nursing.

Group B, to validate the content of a game, consisted of 40 experts, mostly female (87.5\%) from the professional nursing area (67.5\%) and with a mean age of 47.83 years old (Table 1).
Table 2 shows the questions (P) versus answers (R) and the respective degree of agreement, given the relevance of the item and its statement. For all items, a percentage of agreement regarding relevance of $100 \%$, and clarity greater than $75 \%$, ranging between $100 \%$ and $75 \%$ agreement, according to the previously established inclusion criteria, was observed.

Considering the total number of items, using non-parametric tests it was found that the distribution of agreement is the same between the gender categories $(p=0.337)$. We verified that the distribution is the same between the age class categories $(p=0.252)$. Finally, the same distribution was found for the categories of professional practice area $(p=0.082)$. 
Table 1 - Characterization of Group B experts. Portugal, 2020

\begin{tabular}{|c|c|c|}
\hline Variables & $\mathbf{N}$ & $\%$ \\
\hline \multicolumn{3}{|l|}{ Gender $(N=40)$} \\
\hline Male & 5 & 12.5 \\
\hline Female & 35 & 87.5 \\
\hline \multicolumn{3}{|l|}{ Age $(N=40)$} \\
\hline \multicolumn{3}{|l|}{ Mean 47.83} \\
\hline $31-40$ & 8 & 20.0 \\
\hline $41-50$ & 19 & 47.5 \\
\hline $51-60$ & 10 & 25.0 \\
\hline $61-70$ & 3 & 7.5 \\
\hline \multicolumn{3}{|l|}{ Professional practice area $(\mathrm{N}=40)$} \\
\hline \multicolumn{3}{|l|}{ Nursing: } \\
\hline Nursing Professor & 11 & 27.5 \\
\hline $\begin{array}{l}\text { Specialist nurse in child health } \\
\text { and pediatrics }\end{array}$ & 11 & 27.5 \\
\hline family health nurse & 3 & 7.5 \\
\hline Others & 2 & 5.0 \\
\hline Elementary school teacher & 11 & 27.5 \\
\hline Psychology & 2 & 5.0 \\
\hline
\end{tabular}

From the analysis of the results, it was possible to validate the relevance of the items to be included in the Quantos Queres game. Items in which an electronic 100\% of agreement percentage as to the clarity of the P/R was not observed were associated with reformulation proposals. All reformulation proposals were considered in the analysis and discussion in the second stage of discussion by expert group A, given the initial assumptions and limitations imposed by the game's structure, which resulted in a review of the content of some items (Box 2).

As a result of the research path and the results obtained in the different stages, the origami Quantos Queres presented in figure 1 resulted.

\section{DISCUSSION}

The importance of the visibility of a profession is unavoidable for its professionals and for those in need of nursing care, which is why it is urgent to spread it among their clients(5). This dissemination must be continuous among all citizens and with resources to diversified and adjusted tools, an idea supported by world organizations, among which the World Health Organization and the International Council of Nurses stand out, which have promoted, in recent years, the Nursing Now ${ }^{(7)}$ campaign. We believe that the time of pandemic we are currently living has highlighted the nursing profession, so it is an opportunity to carry out marketing.

Professional marketing uses dissemination strategies that can transfer to the target audience a kind of positive

Table 2 - Percentage of agreement on the relevance and clarity of the statement of questions and answers in group B. Portugal, 2020

\begin{tabular}{lcccccccc} 
& \multicolumn{4}{c}{ Relevance } & \multicolumn{4}{c}{ Clarity } \\
Question (P)/ & \multicolumn{3}{c}{ Agree } & \multicolumn{2}{c}{ Disagree } & \multicolumn{2}{c}{ Agree } & \multicolumn{2}{c}{ Disagree } \\
\cline { 2 - 9 } Answer(R) & $\mathbf{N}$ & $\%$ & $\mathbf{N}$ & $\%$ & $\mathbf{N}$ & $\%$ & $\mathbf{N}$ & $\%$ \\
\hline$P 1-R 1$ & 40 & 100.0 & 0 & 0.0 & 34 & 85.0 & 6 & 15.0 \\
$P 2-R 2$ & 40 & 100.0 & 0 & 0.0 & 40 & 100.0 & 0 & 0.0 \\
$P 3-R 3$ & 40 & 100.0 & 0 & 0.0 & 30 & 75.0 & 10 & 25.0 \\
$P 4-R 4$ & 40 & 100.0 & 0 & 0.0 & 36 & 90.0 & 4 & 10.0 \\
$P 5-R 5$ & 40 & 100.0 & 0 & 0.0 & 38 & 95.0 & 2 & 5.0 \\
$P 6-R 6$ & 40 & 100.0 & 0 & 0.0 & 35 & 87.5 & 5 & 12.5 \\
$P 7-R 7$ & 40 & 100.0 & 0 & 0.0 & 38 & 95.0 & 2 & 5.0 \\
$P 8-R 8$ & 40 & 100.0 & 0 & 0.0 & 38 & 95.0 & 2 & 5.0 \\
\hline
\end{tabular}

Source: Research data, 2020. 


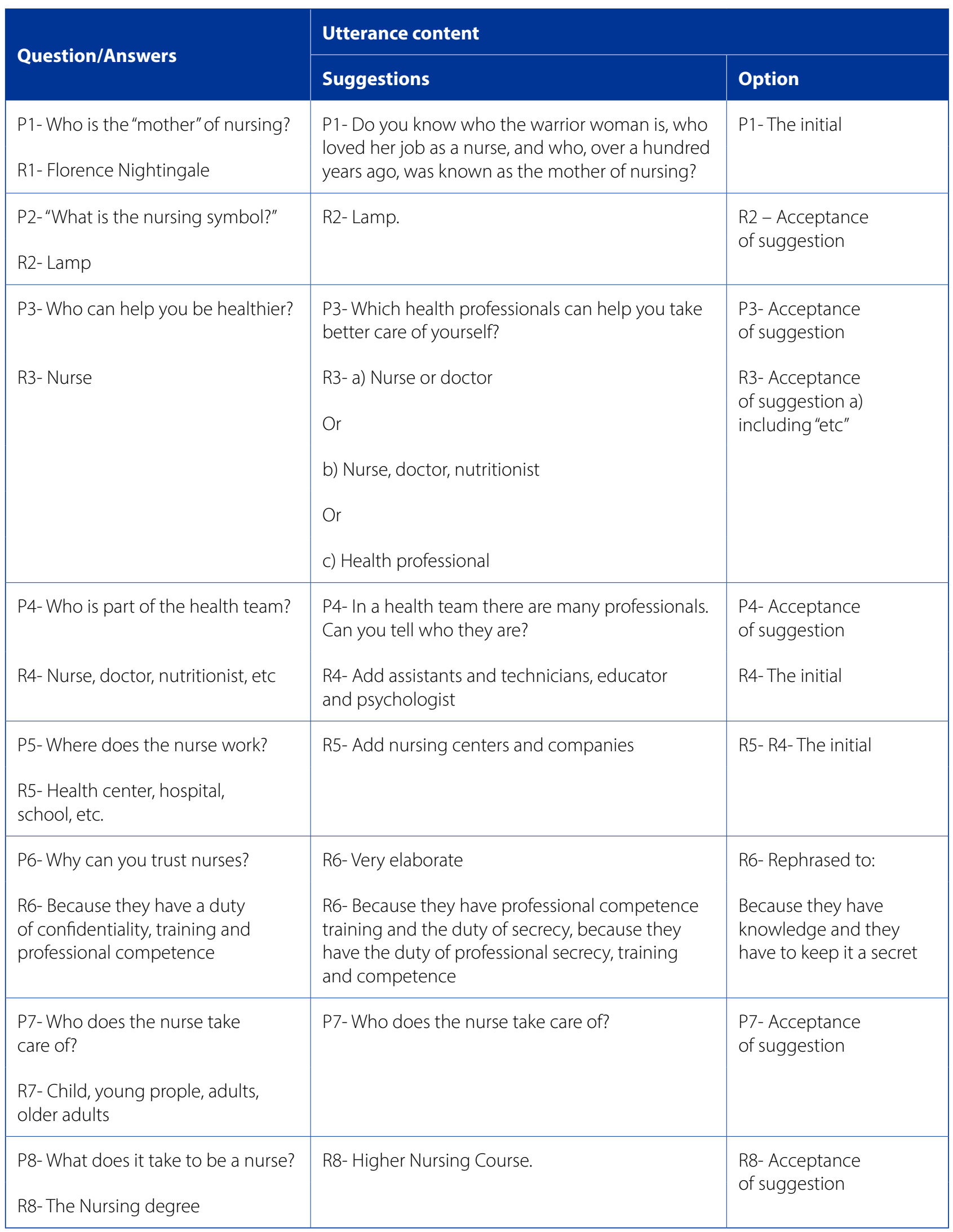

Box 2 - Initial statements, reformulation suggestions for expert group B and final statement for expert group A. Portugal, 2020 Source: Research data, 2020. 


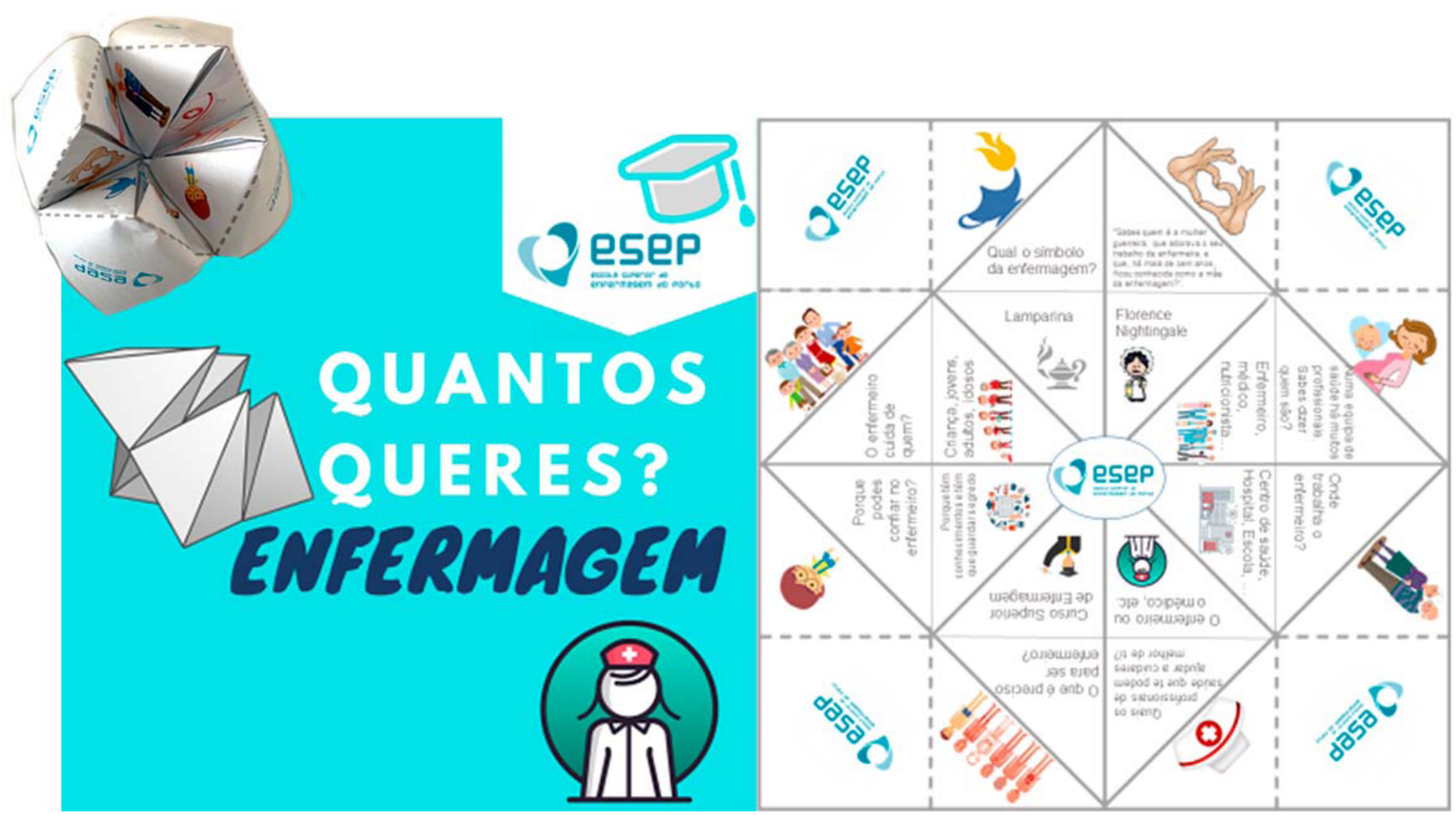

Figure 1 - Origami illustration - Quantos Queres. Portugal, 2020 Source: The authors, 2020.

image of the profession depending on the content used, so its selection must be judicious and careful when aiming to change the population's behavior and attitudes involved ${ }^{(5)}$.

Remember that the objective of this path is to intervene in this target group in order to promote a positive image of nursing. In fact, the positive contributions to nursing need to be conveyed, ideally authored by the nurses to assist in training and valid and accurate ideas about nursing and correcting any misperceptions ${ }^{(15)}$. In general, the image that is transmitted to us through nursing is of someone with a secondary role associated with another profession, without responsibility, autonomy or decision-making capacity. A poor image is projected, with a low academic level, with limited career opportunities, little pay and little social value ${ }^{(16)}$. Children are sensitized, and, therefore, each representation of nurses must give them a meaning that will help them understand who they are and what they do ${ }^{(15)}$.

The game may be one of the most robust strategies to promote the Nursing profession among the young people due to the numerous advantages that are recognized for it. In childhood, recreational activities are a resource for cognitive development. From a Piagetian perspective, the child learns new information and accommodates it in their mental structures. Among the recreational activities, the experimental game works as a connector between the motor, cognitive, affective and social components, with which the child will shape the world around them, appropriating experiences, information, activities, attitudes and values. Thus, it cooperates with the formation of knowledge, mediating significant learning. But for this to produce the desired results, the game's design, the age group and the sociocultural context must be considered. Through the game, the child learns by having fun ${ }^{(8-9)}$.

The game will be an effective marketing tool to raise awareness of the nursing profession as a health resource among young people. Among the experimental games, we highlight those that use the origami technique, in which paper folds form different figures. This enhances the development of motor skills, logical-mathematical reasoning, perseverance and patience; stimulates concentration and activates memory, promoting the integration of knowledge ${ }^{(17)}$.

Considering the potential of the origami technique, our focus was on the "type" and "how", considering the developmental issues of the group in question and the absence of tools that aim and disseminate the nursing profession. As previously mentioned, we did not find in the literature the use of this resource to enhance the visibility of the profession in this age group. However, there are studies with its use used 
in various fields (mathematics, engineering, technology, education, psychology and health care ${ }^{(17-18)}$. In a study carried out by these authors, with children in oncology, they highlight the advantages of its use, among them it is safe, cheap and interactive, self-creation leading to a sense of achievement, innovative, easy to do, they become the characters in the stories, it can be made and used in any context ${ }^{(18)}$.

The selection of contents took into account the pillars of the profession: professional practice profile, qualifications to access the profession, ethical principles that support it ${ }^{(19)}$ and also the historical and symbolic elements that portray it. The agreement in the selection of items by the expert groups reinforces their importance.

We are aware of the importance of choosing this tool, because according to Franco Cofre ${ }^{(20)}$ the social image of the nursing profession is still a deteriorated image, associated with past stigmas. Nurses are the main responsible for the construction of a solid professional identity and image that permeates society.

The choice of the terms in which the message was written proved to be the most challenging task, the brevity of the message as well as its relevance and clarity were criteria in its elaboration.

The effort to change the image we transmit is on the hands of Nursing. We must publicly project the best of our identity and build in the minds of the population, for whom we work, a positive image that generates trust and, consequently, guarantees the maximum use of the resources we can offer. Thus, we will achieve improvements in our current position, visibility of nursing care and our projection for the future, in this path focusing on children from an early age ${ }^{(15)}$.

The game must be seen as a sociocultural activity, allowing the identification of the central aspects to be integrated so that the message can be understood, emphasizing the importance of the way it is presented. Without pretentiousness, we believe that the game Quantos Queres with the origami technique can be an artifact to be used in marketing campaigns for the nursing profession with young people.

\section{$\square$ CONCLUSION}

Considering the guiding objectives of this methodological study, the contents to integrate an experimental game, Quantos Queres, were identified and validated, using the origami technique, on the Nursing profession, aimed at children between 7 and 12 years old.

This study will proceed to the prototype construction phase and its validation with the target population. Its limitation is based on the low representation of experts in the education field.
This game will contribute to the visibility of the nursing profession, which assumes greater impact in times of COVID 19 pandemic. Its use in the school and/or family context makes it an instrument that makes the recognition of this professional group easier, as a health resource, with the society.

\section{QREFERENCES}

1. Correia M, Correia S, Santos MF, Lourenço A. A enfermeira no desenho da criança. Rev EnfRef. 2010 [cited 2020 Nov 3];2(12):83-92. Available from: https://www. redalyc.org/pdf/3882/388239959002.pdf

2. Donoso MTV, Wiggers E. Discorrendo sobre os períodos pré e pós Florence Nightingale: a enfermagem e sua historicidade [reflexão]. Enferm Foco. 2020 [cited 2020 Nov 3];11(1.esp):58-61. Available from: http://revista.cofen.gov. br/index.php/enfermagem/article/view/3567/803

3. Martins MF, Dias MO. Representação socioprofissional dos enfermeiros - percepção dos utentes. Rev Mill. 2010 [cited 2020 Nov 3];38(15):253-69. Available from: https://revistas.rcaap.pt/millenium/article/view/8261

4. Ordem dos Enfermeiros [Internet]. Coimbra: OE; 2019 [cited 2020 Nov 3]. Nursing Now; [about 2 screens]. Available from: https://www.ordemenfermeiros.pt/ centro/noticias/conteudos/nursing-now/

5. Andrade JB, Cavalcante BM., Apostólico MR. Marketing pessoal e enfermagem: projeção para visibilidade social do enfermeiro. Enferm Foco. 2017,8(1):82-6. doi: https://doi.org/10.21675/2357-707X.2017.v8.n1.946

6. Mo Y, Deng L, Zhang L, Lang Q, Liao C, Wang N, et al. Work stress among Chinese nurses to supportWuhan for fighting against the COVID-19 epidemic. J Nurs Manag. 2020;28(5):1002-9. doi: https://doi.org/10.1111/jonm.13014

7. Ordem dos Enfermeiros Enfermeiros [Internet]. Coimbra: OE; 2019 [cited 2020 Nov 3]. Nursing Now Portugal - faça parte deste movimento!; [about 1 screen]. Available from: https://www.ordemenfermeiros.pt/noticias/conteudos/ nursing-now-portugal-fa\%C3\%A7a-parte-deste-movimento/

8. Luiz JMM, Santos ACB, Rocha FF, Andrade SC, Reis YG. As concepções de jogos para Piaget, Wallon e Vygotski [Internet]. Cafelândia: Colégio John Kennedy; 2015 [cited 2020 Nov 3]. Available from: http://www.colegiojohnkennedy.com.br/ downloads/2015/AnaLucia-03-10/J0G0.pdf

9. Dantas GP. 0 brincar no desenvolvimento infantil. São Paulo: Senac; 2017.

10. Azevedo Neta SL, Castro DL. Teorias da aprendizagem: fundamento do uso dos jogos no ensino de ciências. Rev Ciênc Ideias. 2017;8(2):195-204. doi: http:// doi.org/10.22407/2176-1477/2017v8i2.641

11. Fink A, KosecoffJ, Chassin M, Brook RH. Consensus methods: characteristics and guidelines for use. AJPH. 1984;74(9):979-83. doi: https://doi.org/10.2105/ AJPH.74.9.979

12. Souza DJ, Contim D, Ferreira MBG, Costa NS, D'Innocenzo M. The delphi method in research in the field of nursing: a bibliometric study. J Nurs UFPE on line. 2015 [cited 2020 Nov 3]:9(9):9216-23. Available from: https://periodicos.ufpe.br/ revistas/revistaenfermagem/article/view/10720/11808

13. Dalla Nora CR, Zoboli E, Vieira MM. Validation by experts: importance in translation and adaptation of instruments. Rev Gaúcha Enferm. 2017;38(3):e64851. doi: http://doi.org/10.1590/1983-1447.2017.03.64851

14. Nishida Y. Something old, something new, something borrowed, and something Froebel? the development of origami in early childhood education in Japan. Paedagog Hist. 2019;55(4):529-47. doi: https://doi.org/10.1080/00309230. 2018.1546330 
15. Carroll SM, Rosa KC. Role and image of nursing in children's literature: a qualitative media analysis. J Pediatr Nurs. 2016;31(2):141-51. doi: http://doi.org/10.1016/j. pedn.2015.09.009

16. Sánchez-Gras $S$. Imagen de la enfermería a través de la prensa escrita ¿necesitamos visibilizar los cuidados enfermeros? Cult Cuid. 2017;21(49):74-80. doi: http:// doi.org/10.14198/cuid.2017.49.08

17. Menezes JPC. Origami como recurso didático para o ensino de ciências. REnCiMa. 2018;9(3):238-48. doi: https://doi.org/10.26843/rencima. v9i3.1304
18. Patni N, Patni S, Bapna A, Sharma L, Sharma U. Origami in Oncology: coping with children. Indian J Med Paediatr Oncol. 2019;40(3):430-1. doi: http://doi. org/10.4103/ijmpo.ijmpo_124_19

19. Ministério da Saúde (PT). Decreto-Lei n.o 161/96, de 4 de setembro de 1996. Regulamento do exercício profissional do enfermeiro. Diário da República. 1996 set 4 [cited 2020 Nov 3];(205 1 Série A):2959-62. Available from: https://dre. pt/application/conteudo/241640

20. Franco Coffré JA. Percepción social de la profesión de enfermería. REVENF. 2020;(38):272-81. doi: http://doi.org/10.15517/revenf.v0i38.36930 


\section{- Authorship Contribution:}

Conceptualization: Luísa Maria da Costa Andrade, Maria Manuela Ferreira Pereira da Silva Martins, Carla Sílvia Fernandes, Henriqueta Ilda Verganista Martins Fernandes.

Data curation: Luísa Maria da Costa Andrade, Maria Manuela Ferreira Pereira da Silva Martins, Carla Sílvia Fernandes, Henriqueta Ilda Verganista Martins Fernandes.

Formal analysis: Luísa Maria da Costa Andrade, Maria Manuela Ferreira Pereira da Silva Martins, Carla Sílvia Fernandes, Henriqueta Ilda Verganista Martins Fernandes.

Investigation: Luísa Maria da Costa Andrade, Maria Manuela Ferreira Pereira da Silva Martins, Carla Sílvia Fernandes, Henriqueta Ilda Verganista Martins Fernandes.

Methodology: Luísa Maria da Costa Andrade, Maria Manuela Ferreira Pereira da Silva Martins, Carla Sílvia Fernandes, Henriqueta Ilda Verganista Martins Fernandes.

Project administration: L Andrade. Validation: Luísa Maria da Costa Andrade, Maria Manuela Ferreira Pereira da Silva Martins, Carla Sílvia Fernandes, Henriqueta Ilda Verganista Martins Fernandes.

Writing - original draft: Luísa Maria da Costa Andrade, Maria Manuela Ferreira Pereira da Silva Martins, Carla Sílvia Fernandes, Henriqueta Ilda Verganista Martins Fernandes.

Writing - review and editing - Luísa Maria da Costa Andrade, Henriqueta Ilda Verganista Martins Fernandes.

The authors declare that there are no conflicts of interest.

\section{- Corresponding author:}

Luísa Maria da Costa Andrade

Email: luisaandrade@esenf.pt

\section{Associate editor:}

\section{Editor-in-chief:}

Approved: 05.31.2021

Maria da Graça Oliveira Crossetti 